\title{
Nekrolog: Paul Quentin Hirst (1946-2003)
}

Den britiske samfundsteoretiker Paul Q. Hirst, professor i socialteori ved Birkbeck College, University of London, døde pludseligt mandag den 16. juni. Paul Hirst blev uddannet på University of Leicester og University of Sussex i 1960'erne. Han fik begge steder en bred uddannelse, der strakte sig over sociologi, politisk teori, filosofi, videnskabsteori, psykologi, økonomi og historie. Hirst var en del af en stor talentfuld gruppe af unge samfundsforskere, der voksede ud af Leicester-miljøet, hvor bl.a. Norbert Elias, Ilya Neustadt, Barry Hindess og Anthony Giddens medvirkede til at skabe et utroligt inspirerende intellektuelt miljø. Hirst forlod Leicester med højeste karaktergennemsnit og tog til Sussex, hvor den verdenskendte sociolog Tom Bottomore stimulerede Hirst yderligere. Hirst blev umiddelbart efter sin eksamen fra Sussex $i$ en alder af 23 år ansat som adjunkt ved Birkbeck College hyret af den nærmest legendariske politiske tænker Bernard Crick. Inden Hirst var fyldt 30 havde han skrevet to bemærkelsesværdige bøger om videnskabsteori, evolutionsteori og socialteori. Hirst var i sine yngre år $i$ en vis forstand marxist. Inspireret af den franske tænker Louis Althussers læsning af Marx forfattede Hirst sammen med Barry Hindess bogen Pre-Capitalist Modes of Production, som skabte en voldsom debat. Hirst og Hindess var blandt de få, der for alvor tog Althusser på ordet og læste Althusser med Althussers egne briller. Det førte til et brud med væsentlige dele af Althussers tænkning, da de påviste inkonsistens $\mathrm{i}$ hans teori og for både Hirst og Hindess førte det til et brud med marxismen længe før den Kolde Krigs ophør. Det førte endvidere Hirst ind i kernen af demokrati- og politisk teori. Hirst blev kendt for sit bidrag til demokratiteorien i form af en styrkelse af civilsamfundet og frivillige foreninger og organisationers rolle - teorien om det associative demokrati. I 1996 udgav han sammen med Grahame Thompson bogen Globalization in Question, som blev en akademisk bestseller. Bogen antaster tesen om den globaliserede verden og udmærker sig ved teoretisk og empirisk dybde, som kun få bøger inden for genren kan bryste sig af. I 2001 udgav Hirst War and Power in the 21st Century, som demonstrerede hans store historiske indsigt med knivskarp teoretisk analyse af det moderne statssystem, fremtidens krig og mulige konfliktområder. Paul Hirst var en usædvanlig "scholar" og en sand polyhistor. Det særlige ved Hirst består ikke blot i hans omfattende produktion af en udsædvanlig høj kvalitet. Således nåede han ganske vist at publicere mere end 25 bøger, et utal af artikler, kommentarer, anmeldelse, bidrag til aviser, magasiner og han forelæste verden over. Hans bøger er oversat til mere end 15 forskellige sprog. Det særegne ved Hirst var derimod hans enorme brede og dybe viden og interesse for mange felter. Han var 
politisk aktiv i Charter 88 , en borgerrettighedsbevægelse, der kæmpede for en skriftlig forfatning i Storbritannien. Her var han i flere perioder i forretningsudvalget og leder heraf. Desuden underviste Hirst på Architectural Association (AA) i London, den vel mest prominente arkitektskole i Europa. Han underviste i byplanlægning, arkitektur, kunsthistorie, socialteori, rum og territorialitet. I midten af 90'erne startede han London Consortium, som var og er et af de mest innovative forsøg på at lave en kandidat- og forskeruddannelse inden for humaniora og kulturstudier. London Consortium er en fusion mellem fire kulturinstitutioner (Tate Gallery, Architectural Association, Birkbeck College og Institute of Contemporary Art). Hirst var Academic Director for London Consortium indtil sin død. Hirst var én af de få, der i sin levetid nåede at blive tilbudt professorater i så forskellige fag som sociologi, politisk teori, international politik, jura, international politisk økonomi, kulturforskning, arkitektur, kunsthistorie, krigsstudier og historie. Han kunne i enkelte uger om mandagen deltage $i$ en paneldiskussion med filosoffen J. Derrida i Oxford, om tirsdagen undervise i politisk teori i London, om onsdagen deltage i et G7-møde for at diskutere arbejdsløshedstal og inflationsrater med gamle statsledere som Helmuth Smith for at slutte ugen med et møde i Charter 88 og nogle foredrag om Gombrich's kunsthistorie på en arkitektskole. Hirst var usædvanlig i en tid, hvor specialisering er en dyd. Hans store generelle, men alligevel dybe viden ses sjældent $\mathrm{i}$ vor tid, hvor flere og flere koncentrerer sig om at vide mere og mere om mindre og mindre. Adskillelsen mellem fag og mellem discipliner bliver større og helhedsperspektiver forsvinder. Med Hirst forsvinder én af de sidste, der formåede at tænke i helheder og på tværs af samfundsvidenskab, humaniora og naturvidenskab. Hirst gæstede ofte Danmark som foredragsholder, optrådte adskillige gange på dansk TV og radio samt i danske aviser og flere af hans bøger er oversat til dansk herunder Globalisering, demokrati og det civile samfund (1997), Globalisering til debat (2001) og Krig og magt $i$ det 21. århundrede (under udgivelse) - alle på Hans Reitzels Forlag.

Lars Bo Kaspersen 